\title{
Life-history traits of Alcyonium acaule and Parazoanthus axinellae (Cnidaria, Anthozoa), with emphasis on growth
}

\author{
Joaquim Garrabou* \\ Departament d'Ecologia, Universitat de Barcelona, Avgda. Diagonal 645, E-08028 Barcelona, Spain
}

\begin{abstract}
Lite-history aspects of 2 common cnidarians, Parazoanthus axinellae and Alcyonium acaule, were studied in the northwestern Mediterranean over 2 yr. Rates of growth (i.e. area gained) and shrinkage (i.e. area lost), colony fission and fusion, mortality, feeding activity and preliminary data on recruitment (for $A$. acaule) were measured. Independent growth and shrinkage rates of $P$. axinellae were measured as area gained and lost per month respectively using a photographic and computerassisted image analysis. Measurement of growth in $A$ acaule was based on size variations of the colonies over 2 yr. Results indicated moderate growth dynamics for $P$. axinellae and very slow growth by $A$. acaule. Growth rates and shrinkage rates in $P$. axinellae showed non-significant differences over time, although growth rates peaked during summer to autumn periods for both monitored years. In general, growth dynamics for the cnidarians studied were similar to or lower than those reported for related species from temperate and tropical habitats. Fission events were common in $P$. axinellae. Of the colonies monitored, $29 \%$ underwent at least 1 fission event in 2 yr. Fusion events occurred less frequently; only $8 \%$ underwent 1 fusion event. Neither fusion nor fission occurred in $A$. acaule. Mortality rates were about $10 \% \mathrm{yr}^{-1}$ for both species. Preliminary data showed low recruitment rates for $A$. acaule. Data on life-history traits were interpreted as evidence for distinct biological strategies used to persist and to occupy new substrata. $P$. axinellae based its strategy on a greater dynamic spreading over the substrata at moderate rates, by somatic growth and by fission. In contrast, $A$. acaule showed relatively slow growth but greater longevity.
\end{abstract}

KEY WORDS: Mediterranean C Clonal organisms - Cnidaria - Alcyonacea - Zoanthidea - Life-history Growth rate Shrinkage rate

\section{INTRODUCTION}

Cnidarians can be dominant space occupiers in many marine sublittoral habitats (e.g. True 1970 , Benayahu \& Loya 1981). Due to the quantitative importance of cnidarians, knowledge of their main life history traits could help us understand the structure and dynamics of the communities where they thrive. Cnidarians are clonal organisms. Like other clonal animals (e.g. ascidians, bryozoans), they grow by the repeated replication of structural units, i.e. modules (e.g. polyps in corals, zooids in bryozoans). This orga-

- Present address: Station Marine d'Endoume, CNRS-UM 6540 DIMAR, rue Batterie des Lions, F-13007 Marseille, France.

E-mail: garrabou@porthos.bio.ub.es nization potentially liberates clonal organisms from many of the morphological and physiological limitations affecting aclonal organisms such as maximum size, senescence, surface-area-to-volume ratio, and confers on them the ability to asexually reproduce (fragmentation and fission capabilities) and high regenerative abilities (Jackson 1977. Hughes \& Cancino 1985).

Life-history theory predicts schedules of sexual reproduction and somatic investment under different regimes of mortality (Stearns 1992). However, since this theory was formulated on the basis of aclonal organisms (Fisher 1958, Pianka 1976), whether its predictions apply to clonal metazoa remains unclear (Hughes \& Cancino 1985). In particular, the failure to consider asexual reproduction (i.e. production of sepa- 
rate ramets from a single genet sensu Harper 1977) hinders the ready application of life-history theory to clonal organisms (Hughes 1989). Despite the differences in life-history traits between clonal and aclonal organisms (Jackson 1977), the available evidence suggests that clonal metazoa invest in sexual and nonsexual processes, according to environmental conditions, in much the same way as aclonal organisms (Hughes \& Cancino 1985). Nevertheless, further empirical data on life-history of clonal organisms are needed before appropriate theoretical models can be formulated (Hughes \& Cancino 1985).

Studies of the life-history traits (e.g. survival, recruitment, growth) of cnidarians have been carried out mainly in coral reef habitats (e.g. Bak \& Engel 1979, Hughes \& Jackson 1985, Benayahu \& Loya 1987). Data available from other habitats are more limited (e.g. Sebens 1983, 1984, Farrant 1987). In the Mediterranean Sea, cnidarians are common in sublittoral rocky communities, especially in habitats with low light irradiance (enough to limit algal growth) and with moderate to high water movement (True 1970, Weinberg 1978, Gili \& Ros 1985a). Despite their abundance, studies of life history traits of Mediterranean cnidarians are relatively scarce (e.g. Weinberg \& Weinberg 1979, Harmelin 1984, Boero et al. 1986, Llobet et al. 1991, Mistri \& Ceccherelli 1994, Coma et al. 1998).

The capacity of cnidarians, as in other clonal organisms, to reproduce, compete, recover and survive should increase with size (Jackson 1977, Hughes \& Cancino 1985). Therefore, growth dynamics, which should strongly contribute to the size of colonies, becomes one of the most important parameters for trying to understand other life-history traits of cnidarians. As a consequence of the indeterminate and plastic growth shown by most cnidarians, assessment of colony growth can be complex. For instance, uneven growth within the same colony may result in one part growing and in another shrinking. Furthermore, the growth plasticity may result in a great variability among conspecifics. Therefore, reliable estimates can be obtained only if studies on growth dynamics are based on the repeated measurement of sizes of sets of colonies (Hughes 1989).

We selected the anthozoans Alcyonium acaule Marion, 1878 and Parazoanthus axinellae (O. Schmidt, 1862) since they are abundant and widespread in the NW Mediterranean (Herberts 1972a, Weinberg 1977). Both species dwell on rocky bottoms at depths ranging from 12 to $45 \mathrm{~m}$ (light conditions from 1.1 to $5.6 \%$ of light at sea surface) for $A$. acaule (Weinberg 1975) and from 5 to $50 \mathrm{~m}$ for $P$. axinellae (Gili et al. 1987). In some cases, these species form dense aggregations (Pérès \& Picard 1964, Gili et al. 1984), which reinforces the role of these species in community organization.
This study was designed to gather the first demographic data on Alcyonium acaule and Parazoanthus axinellae. From 2 yr of photographic surveys of permanent sites, colonies were measured for growth (i.e. area gain), shrinkage (i.e. area loss), fission (i.e. division of colonies) and fusion (i.e. coalescence of 2 colonies), mortality and recruitment rates. Data are interpreted in terms of different strategies to occupy space and to persist.

\section{MATERIAL AND METHODS}

Study site, communities and species. The study was carried out on an exposed north-oriented sublittoral wall ( 0 to $35 \mathrm{~m}$ depth) in the Medes Island Protected Area (NW Mediterranean, Spain, 42 $3^{\prime} \mathrm{N}, 3^{\circ} 13^{\prime} \mathrm{E}$ ). In accord with the zonation pattern described in Gili \& Ros (1985b), 2 communities were studied: precoralligenous (extending from 10 to $14 \mathrm{~m}$ depth) and coralligenous communities (extending from 14 to $30 \mathrm{~m}$ depth). These communities are characterized by the dominance of different suspension feeders (mainly sponges, cnidarians, bryozoans and tunicates) and encrusting coralline algae species.

In the study area, Alcyonium acaule is a characteristic species of the precoralligenous community, but it is also common in the coralligenous community (Gili et al. 1984). A. acaule occurs on hard substrata; colonies grow as a cluster of stout finger-like lobes (1 to 20 lobes), and range in height from 1 to $20 \mathrm{~cm}$ (Weinberg 1977). Parazoanthus axinellae is characteristically found in the coralligenous community, in entrances to caves and on overhangs (Gili et al. 1984). Colonies grow as encrusting sheets, as epibionts (mainly over sponges) or directly on the primary substrate (Herberts 1972a, Gili et al. 1987).

A total of 84 colonies of Alcyonium acaule from the precoralligenous community (between 11 and $13 \mathrm{~m}$ ) and 38 colonies of Parazoanthus axinellae from the coralligenous community (between 16 and $18 \mathrm{~m}$ ) were selected. Colonies were chosen from a narrow depth range to avoid the possible effect of depth on growth and survival of the species. The selected set of colonies encompassed most of the colony sizes found at the study site for both species. P. axinellae colonies growing as epibionts were excluded from the monitored set to avoid erroneous growth measurements (see 'Growth rate measurements') due to possible changes in colony positions caused by the expansion and contraction of some underlying species.

Photosampling method. Twenty-two permanent sites were monitored photographically between August 1993 and August 1995 at bimonthly and quarterly intervals for Parazoanthus axinellae and Alcyonium 
acaule, respectively. Most photographs were taken around noon. The sites were marked with 2 tube clips attached to the rock (50 to $70 \mathrm{~cm}$ apart). The tube-clips, together with a PVC domestic set-up, fixed the camera, ensuring that photographs were obtained from the same position and focal distance (see Garrabou 1998 for further information). A Nikonos $V$ camera equipped with a $28 \mathrm{~mm}$ and a close-up lens, and with 2 electronic strobes, was used. These lenses allowed us to monitor an area of $310 \mathrm{~cm}^{2}$ and usually to identify colonies over $4 \mathrm{~mm}^{2}$. The distance between the 2 tube clips plus the lens used allowed us to monitor 2 distinct plots in each site, thus a total of 44 permanent plots $\left(310 \mathrm{~cm}^{2}\right.$ in area) were monitored in this study

Growth rate measurements. Previous observations over $1 \mathrm{yr}$ of monitoring indicated that minor changes in colony size occurred in Alcyonium acaule colonies, whereas Parazoanthus axinellae colonies changed size much more rapidly. In addition, differences in colony growth form between these 2 species (erect and lobed for $A$. acaule and encrusting for $P$. axinellae) prevented us from using the same approach to growth determination for both species.

Parazoanthus axinellae: Slides were projected (at approximately 'real' scale) with an inverse projector, and the outlines of selected colonies, as well as characteristic plot marks (e.g. rock scars, sponge colonies), were traced on acetate sheets. Drawings from each plot were assembled manually in a common reference system. Three reference points were marked on each drawing. To reduce alignment errors we took into account colonies' positions and characteristic plot marks. The drawings were scanned and vectorized with IMAT (a program developed by Serveis Científico-Tècnics de la Universitat de Barcelona). Finally, the vectorized images were imported to Arc/Info (GIS).

Each colony was labeled and the area and perimeter were calculated with Arc/Info. All drawings from each plot were merged into a single new image with Arc/ Info overlay routine procedures to determine colony growth. The resulting new composite image contained all the information on colony area changes over time. We took advantage of database Arc/Info facilities to quantify 2 independent rates: growth (i.e. area gained) and shrinkage (i.e. area lost) for each colony and period (see Garrabou 1998 for detailed information). Rates were calculated using the following expression:

relative growth (shrinkage) rate $=$
$\frac{\left[\frac{\text { area gained (lost) between } t_{i} \text { and } t_{i+1}}{\text { area at } t_{i}}\right]}{\text { [time between } t_{i} \text { and } t_{i+1} \text { (in months)] }}$

Expanded colonies were touched firmly during surveys to contract them so as to obtain comparable outlines. Nevertheless, a number of colonies did not appear in a contracted state in the photographs (due to quick return to expanded state or omission of touching). Data from these cases were not considered. When colonies underwent fission and/or fusion events (see 'Fission and fusion events'), the total colony area was calculated as the sum of the areas of all isolated colonies that had formerly belonged to the same colony (fission) or to different colonies (fusion).

Colonies were assigned to 1 of 3 size classes (I: 0 to $100 \mathrm{~mm}^{2}$, II: 100 to $200 \mathrm{~mm}^{2}$, III: $>200 \mathrm{~mm}^{2}$ ) to test the possible relationships between colony size and growth rates and colony size and shrinkage rates. These size classes were chosen both to encompass the range of colony areas found in this site and to maintain adequate sample sizes. Colonies were classified in these size classes based on mean area values resulting from pooling data on colony area for the entire survey.

Alcyonium acaule: Colony size was determined as projected colony area (contracted) obtained from photographs. The colony areas at the inital and final surveys (i.e. photographs from August 1993 and August 1995) were considered for the growth study. Initial colony sizes were plotted against final sizes (i.e. 2 yr interval) for each monitored colony and a FordWaldford plot (Waldford 1946) regression analysis was applied to study the growth rates (as in Sebens 1984).

Since colony size could vary greatly with the state of expansion (i.e. contracted vs expanded), the regression between expanded and contracted colony size was determined to avoid errors in colony size estimations. Repeated size determinations on 40 colonies in both expanded and contracted state were obtained in an interval between surveys ( 2 to $3 \mathrm{mo}$ ), as measurements within the same day (even when expanded colonies were firmly touched) did not reflect the true size of the colonies in their fully contracted state (author's pers. obs.). Measurements of expanded-state colonies were converted to contracted colony size according to the following formula: Area contracted $=23.55+0.55 \times$ Area expanded $(r=0.98, p<0.01)$. This procedure was used in only about $15 \%$ of colonies, since in summer (i.e. August) most of the colonies of Alcyonium acaule were contracted (see Fig. 5).

Fission and fusion events. A fission event was noted when 1 colony split into 2 physically separate colonies between 2 consecutive sampling dates, while a fusion event was noted when 2 physically separate colonies fused into a single colony between 2 consecutive sampling dates. If a colony split into 3 colonies, 2 fission events were noted; likewise, if 3 colonies fused, 2 fusion events were recorded, and so on. Two descriptive measures of fission and fusion events were determined: (1) fission and fusion rates as the percentage of colonies that underwent fission or fusion between 2 sampling times, and (2) the number 
of fission or fusion events in each colony between 2 sampling times.

Recruitment. When a colony of Parazoanthus axinellae or Alcyonium acaule not previously observed appeared in the permanent plots, it was considered as a recruit. However, before assigning the new colony as a recruit, particular care was taken to discount any possible origin other than sexual recruitment, especially asexual origin (i.e. fission or fragmentation processes from neighboring colonies). The total area surveyed for $P$. axinellae and $A$. acaule was $0.5 \mathrm{~m}^{2}$ and $0.8 \mathrm{~m}^{2}$, respectively.

Whole mortality rate. Mortality rate was defined as the percentage of colonies that disappeared over a $1 \mathrm{yr}$ period. In Alcyonium acaule, we also searched for the relationship between mortality and colony size. Colonies were assigned to 1 of 3 size classes (I: 0 to 100 $\mathrm{mm}^{2}$, II: 100 to $500 \mathrm{~mm}^{2}$, III: $>500 \mathrm{~mm}^{2}$ ) considering the colony size in August 1993.

Feeding activity rhythms. The state of expansion of 80 to 100 colonies of Parazoanthus axinellae and Alcyonium acaule were periodically recorded (minimum once a month) throughout the 2 y of monitoring. For $A$. acaule, data came from the photographs and visual censuses carried out at the study site. For $P$. axinellae, data were obtained only from photographs of permanent plots not used in the study of growth. Two expan- sion states were considered: expanded (i.e. with polyps outside the body) and contracted (i.e. polyps inside the body). A third state of expansion, dormancy, was recorded in $A$. acaule. In this state colonies are completely contracted and covered by a bright film. Colonjes in dormancy were recorded only from photographic surveys, since colonies in this state are usually covered by epibionts, and so may not have been noticed during the in situ censusing of the colonies. For the study of activity rhythms in A. acaule, both sources of data were pooled together, considering colonies in dormancy as colonies in contracted state.

Statistical methods. Permutation tests were used to test for differences in growth and shrinkage rates through time and among size classes in Parazoanthus axinellae. Permutation tests used, based on Manly (1991), consisted of a 2-stage permutation of data. First, data from each colony were reassigned among the 3 size classes. Second, readings for each colony were randomly rearranged among observation times. Then, the sum of squares associated with each factor and their interaction were calculated. This procedure was repeated 4999 times (plus the observed one) to obtain the frequency distribution of the sum squares of each factor and their interaction. The values of the statistics for the observed data were compared in these distributions. The null hypothesis (no effect) is ac-

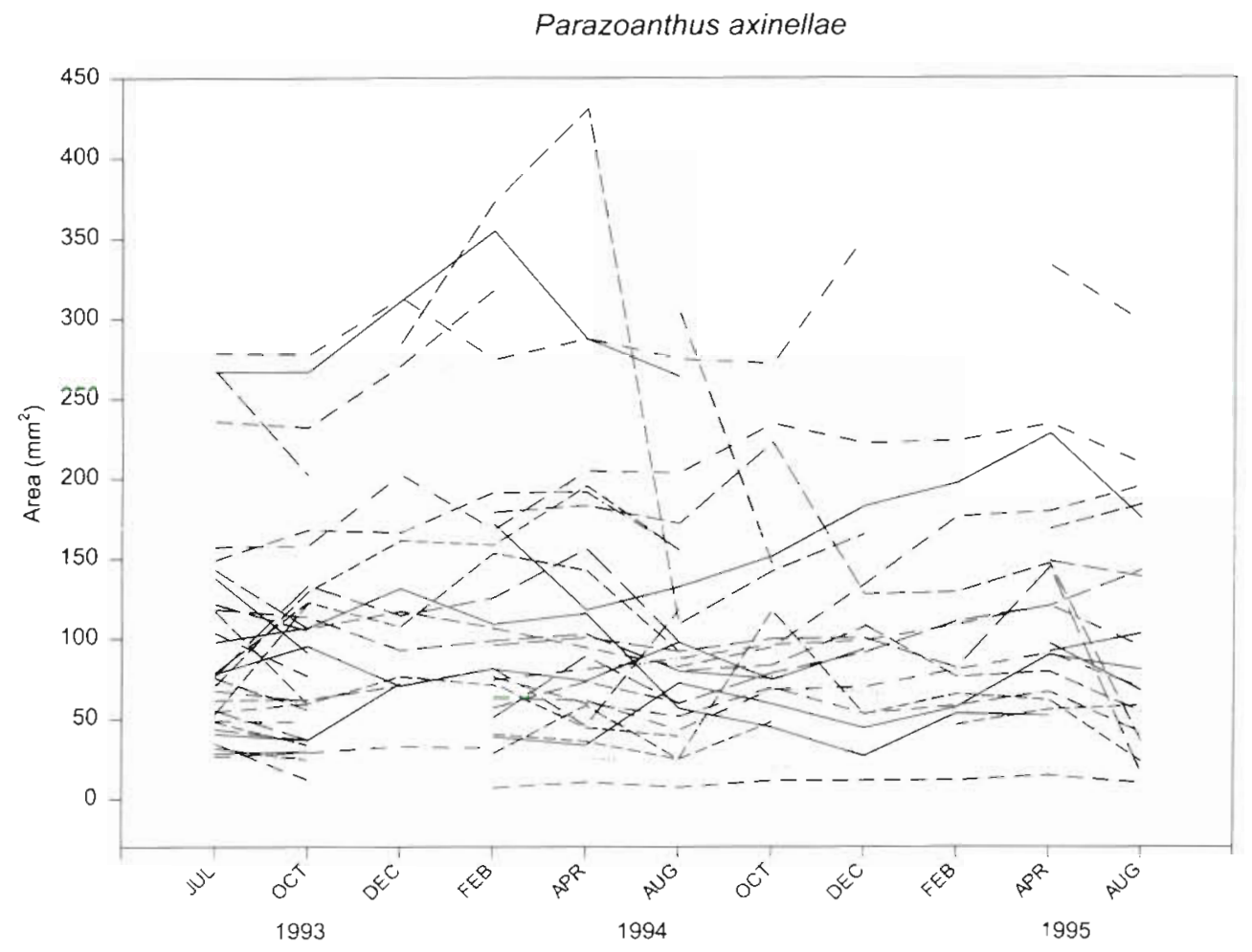

Fig. 1. Parazoanthus axinellae. Changes in surface area of colonies monitored between August 1993 and August 1995 
cepted if, for a given significance level, the value of the statistic for the observed data is as likely as values obtained by randomly reordering the data. Conversely, if the value of the statistic for the observed data is an atypical (infrequent) value of the distribution, the null hypothesis is rejected, and the alternative hypotheses accepted (see Crowley 1992 for further information on permutation tests). A modified version of the Turbopascal program used by Turon et al. (1998) was applied to perform the permutation tests.

\section{RESULTS}

\section{Growth rates}

\section{Parazoanthus axinellae}

In general, minor colony area changes were found (Fig. 1). No clear seasonal patterns in area gain or loss were observed. This is due mainly to (1) the lack of a sustained trend of area acquisition within monitored colonies (i.e. the same colonies that in some periods gained area could lose area in the following period), and to (2) the variability in area acquisition observed among monitored colonies (i.e. while some colonies gained area, others lost area).

Mean and maximum growth rate values were greater than mean and maximum shrinkage rates (Table 1). Growth rates showed seasonal peaks in the autumn $1993\left(0.17 \pm 0.14 \mathrm{mo}^{-1}\right)$ and the summerautumn $1994\left(0.18 \pm 0.14 \mathrm{mo}^{-1}\right)$ intervals; in addition, a minimum peak was detected for the spring-summer 1994 interval, but did not occur in the following year (Fig. 2). The permutation test did not denote significant differences over time for growth rate $(p=0.20)$. Shrinkage rates showed nearly constant values over time, except in the last interval (spring-summer 1995; $0.18 \pm$ $0.16 \mathrm{mo}^{-1}$ ) (Fig. 2). Despite this, the permutation test denoted significant differences over time for shrinkage rate $(p<0.05)$. However, the same analysis without data from the last interval showed non-significant differences $(p=0.80)$.

Growth and shrinkage rates showed similar values by size class (Fig. 3). Accordingly, permutation tests

Table 1. Parazoanthus axinellae. Descriptive statistics for relative growth and shrinkage rates $\left(\mathrm{mo}^{-1}\right)$ measured between August 1993 and August $1995(n=223)$

\begin{tabular}{|lcc|}
\hline & Growth rates & Shrinkage rates \\
\hline Mean $( \pm S D)$ & $0.11( \pm 0.17)$ & $0.09( \pm 0.12)$ \\
Maximum & 1.88 & 0.66 \\
Minimum & 0 & 0 \\
\hline
\end{tabular}

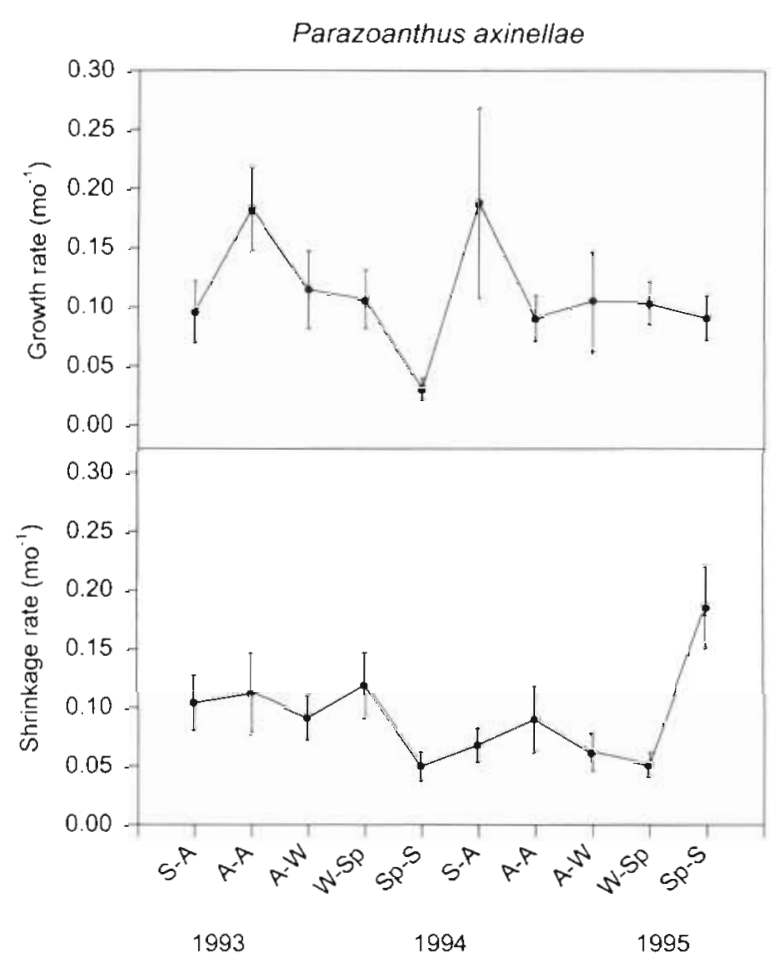

Fig. 2. Parazoanthus axinellae. Relative growth and shrinkage rates (mean $\pm \mathrm{SE}$ ), based on measurements of change in colony areas between August 1993 and August 1995. For seasonal intervals $S=$ summer, $A=$ autumn, $W=$ winter and $S p=$ spring

did not denote significant differences either in growth $(p=0.56)$ or shrinkage $(p=0.82)$. The interaction effects were not significant in any analysis.

\section{Alcyonium acaule}

Most colonies changed little in size over the $2 \mathrm{yr}$ period (Fig. 4). The linear correlation between the initial and final colony area was high and significant $\left(\mathrm{r}^{2}=\right.$ $0.84, p<0.001, n=57$ ), and the slope of the regression line ( $b=0.93$ ) was close to the slope of the line of no growth $(y=x)$. As a result, the overall pattern shows almost zero growth. No clear relationship between growth and colony size arose, since over the whole range of sizes some colonies grew while others shrank (Fig. 4, above or below the $y=x$ line, respectively).

\section{Fission and fusion}

In Parazoanthus axinellae, 11 colonies (29\%) underwent at least 1 fission event during the 2 yr of monitoring. Four of these colonies had further fission events, resulting in a total of 15 fission events recorded. On 

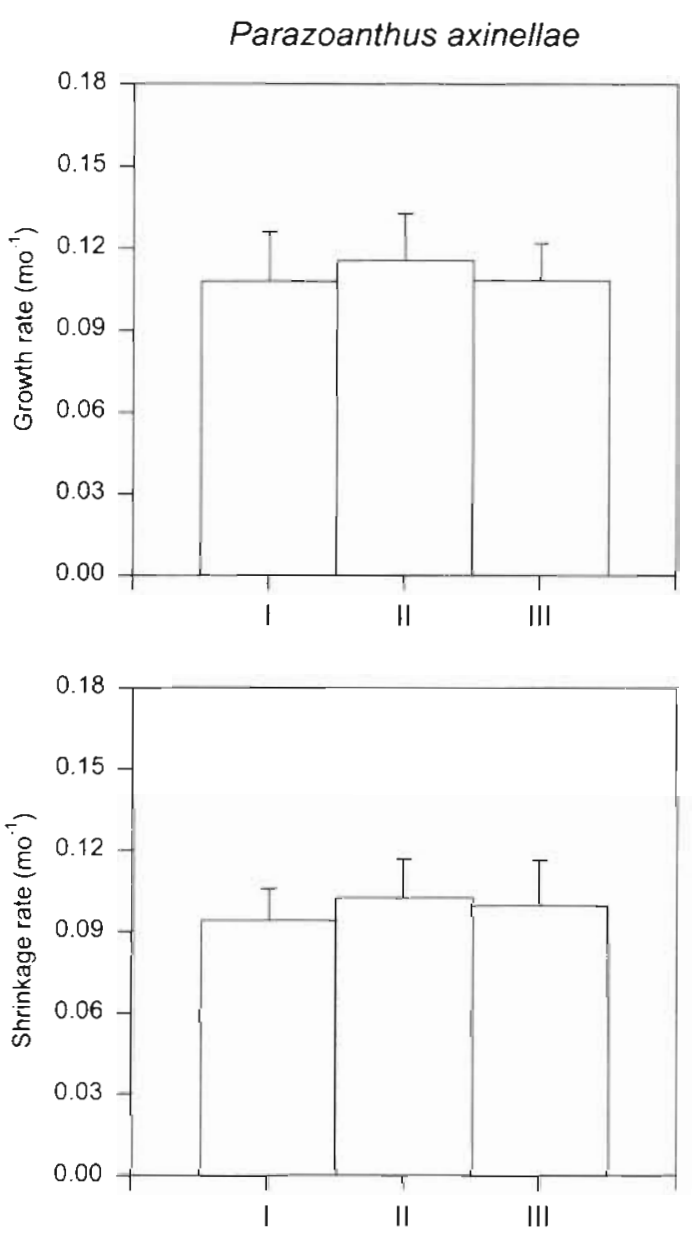

Size class

Fig. 3. Parazoanthus axinellae. Relationships between size and growth and shrinkage rates. Relative growth and shrinkage rates (mean $+\mathrm{SE}$ ) (pooled data from all time intervals) by colony size class (I: 0 to $100 \mathrm{~mm}^{2}$, II: 100 to $200 \mathrm{~mm}^{2}$, III: $>200 \mathrm{~mm}^{2}$ )

average $5 \%$ of the colonies experienced fission in a given period, and those colonies underwent only 1 fission event (i.e. a single split into 2 separate ramets). Fusion events were less frequent, and only 3 colonies $(8 \%)$ experienced fusion. Fusion occurred at rates lower than $1 \%$ of colonies per period, and those colonies underwent only 1 fusion event (i.e. 2 separate ramets fused into a single ramet). In contrast, Alcyonium acaule colonies did not show any fission or fusion events through the 2 yr of monitoring.

In Parazoanthus axinellae, we searched for possible relationships between occurrence of fission and fusion events and colony size previous to the fission or fusion event. Most of the fission and fusion events (87\%) occurred in colonies of size classes II and III (colony area $>100 \mathrm{~mm}^{2}$ ) (fission: chi-squared $=5.95, \mathrm{df}=2, \mathrm{p}=$ 0.051 ; fusion: chi-squared $=5.89, \mathrm{df}=2, \mathrm{p}=0.052$ ).

\section{Recruitment}

Small colonies (with 1 or 2 polyps) of Parazoanthus axinellae were observed always within dense aggregations of this species. Therefore, we were not able to identify Parazoanthus axinellae recruits due to uncertainty about whether small colonies had an asexual or sexual origin. A total of 8 Alcyonium acaule recruits were observed during the 2 yr of study. These recruits were usually visible in autumn photographs.

\section{Whole mortality}

Mortality rates reached values of $9.2 \pm 1.2$ and $12.7 \pm$ $2.2 \% \mathrm{yr}^{-1}$ in Parazoanthus axinellae and Alcyonium acaule, respectively. A total of 7 colonies of the former and 20 colonies of the latter disappeared over the 2 yr study period. Mortality was significantly higher in small colonies of $A$. acaule (colony area less than $100 \mathrm{~mm}^{2}$ and with a single lobe), which accounted for $76 \%$ of colony deaths (chi-squared $=9.35$, df $=2, \mathrm{p}=$ 0.009 ). The low number of deaths in $P$. axinellae hindered any search for a size- mortality relationship.

\section{Feeding activity rhythms}

Data on expansion states of Parazoanthus axinellae and Alcyonium acaule colonies were pooled by season,

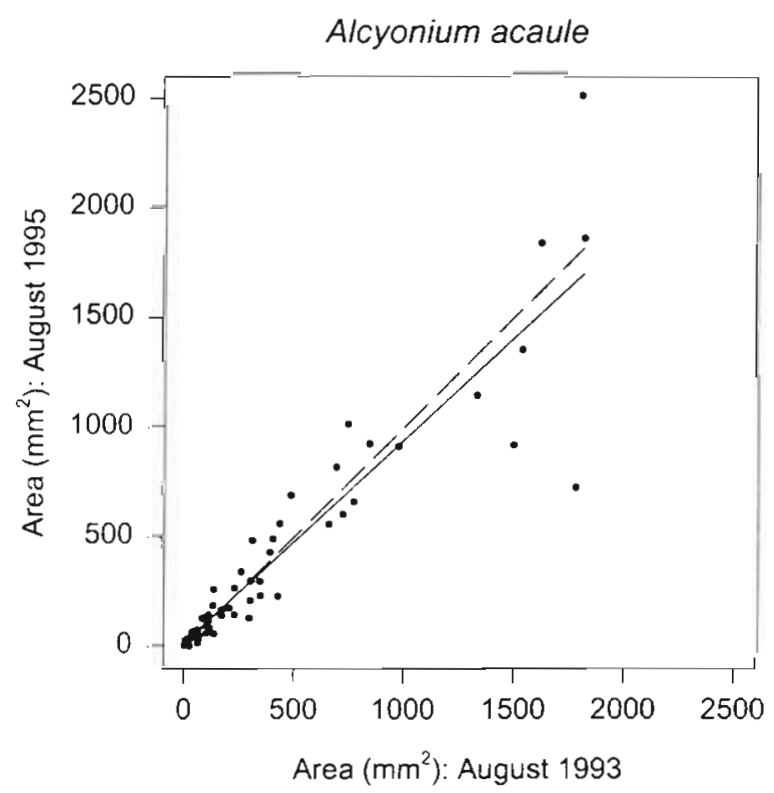

Fig. 4. Alcyonium acaule. Waldford plot of changes in colony size (projected area) from August 1993 to August 1995. Solid line corresponds to linear regression between colony sizes in 1993 and 1995 (A. acaule size $1995=14.36+0.93 \mathrm{~A}$. acaule size 1993) and dashed line corresponds to no growth $(x=y)$ 

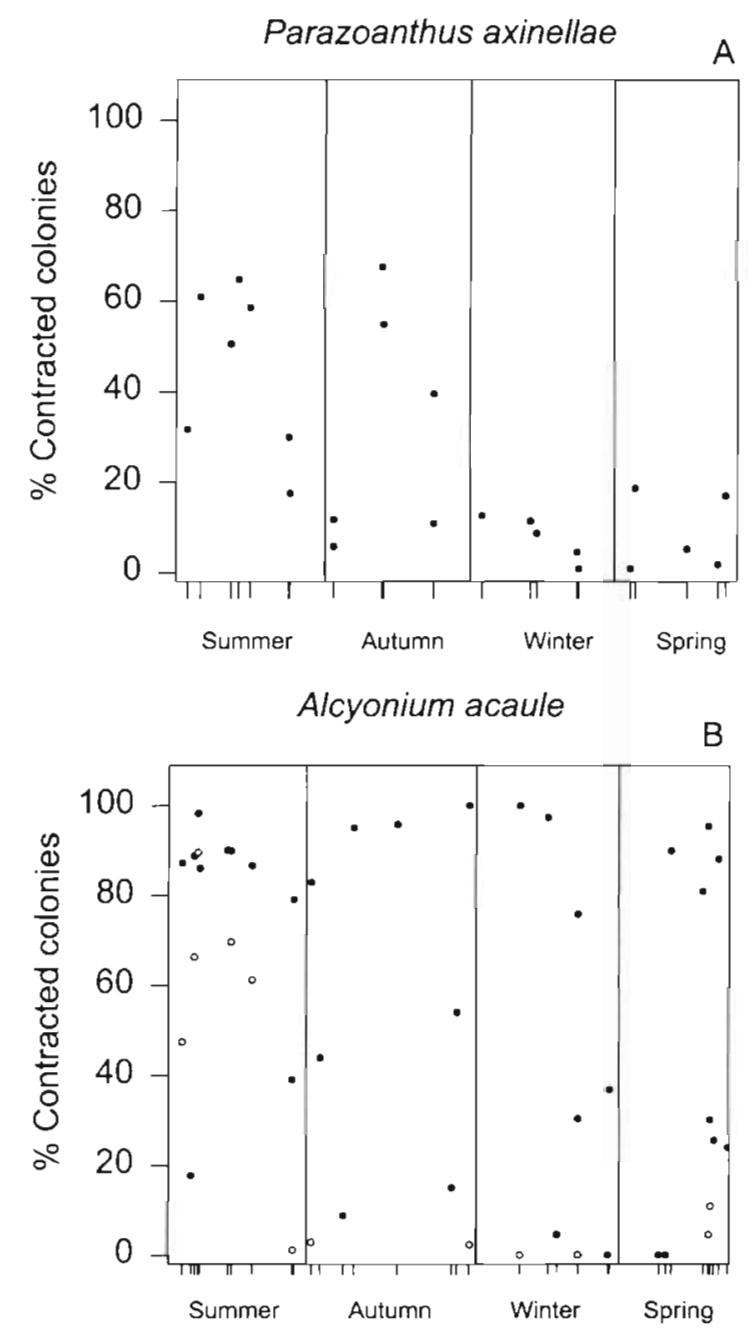

Fig. 5. Parazoanthus axinellae and Alcyonium acaule. Seasonal changes in feeding activity between August 1993 and August 1995 (all survey data on expansion state pooled by season) (•): Percentage of contracted colonies (photographic and in situ counting for $A$. acaule; only photographic for $P$. axinellae); $(0)$ : percentage of colonies in dormancy (photographic counting only)

irrespective of the year of the survey (Fig. 5). In both species, synchrony in expansion between colonies was clear, at any given sampling time most of the colonies were in either expanded or contracted state. Seasonal variations were apparent in Parazoanthus axinellae: colonies in a contracted state were at a low percentage (around 15\%) most of the year, except in summer and mid autumn, when around $60 \%$ of the colonies were in this state. Alcyonium acaule also showed a seasonal pattern: in summer, most surveys showed a high percentage of contracted colonies (up to $80 \%$ ), while in other seasons a similar number of surveys showed high and low percentages of colonies in contraction (Fig. 5). Dormancy state showed an even clearer seasonal pat- tern, with its highest values (up to $90 \%$ ) in summer, while only a small percentage of colonies (less than $5 \%$ ) were in dormant state in other seasons (Fig. 5).

\section{DISCUSSION}

Moderate growth, shrinkage and fission rates and low fusion and mortality rates characterized Parazoanthus axinellae. Low growth rates, no fission or fusion, and moderate mortality rates characterized Alcyonium acaule dynamics. Seasonal patterns were not found either for growth or for shrinkage rates in $P$. axinellae, whereas feeding activity rhythm showed a seasonal pattern for both species.

Great variability in the measurements of growth dynamics, denoted by the large standard deviation in Parazoanthus axinellae (Table 1) and by the deviations from the regression line in Alcyonium acaule, is remarkable. This variability cannot be attributed to environmental conditions. All $P$. axinellae and $A$. acaule monitored colonies were chosen within a narrow depth range where the main ecological factors remained similar. However, particular microhabitat conditions (such as interspecific competition, different food availability, incidence of predation) could be responsible for the variability shown. In fact, such variability is characteristic of most of the parameters measured in colonial organisms (e.g. Ayling 1983, Hughes \& Jackson 1985, Turon \& Becerro 1992).

\section{Growth dynamics}

Parazoanthus axinellae showed moderate dynamics: colonies doubled in size within 1 yr. Direct comparisons of growth rates found in this study with data previously reported should be taken cautiously. First, in previous studies of growth of zoanthid species, measurements were based on polyp counts of tagged colonies over time (Sebens 1982, Karlson 1988). In this study, growth and shrinkage are calculated as net area gained or lost. Second, species previously studied occurred in different environmental conditions (e.g. shallow waters). Unfortunately, the data available for the Mediterranean species is based on surveys of appearance of new polyps in colonies collected at different times (Herberts 1972b), which prevents comparision with our data.

Calculation of the net area increase of Parazoanthus axinellae (i.e. mean growth rate minus mean shrinkage rate) gave a value of $\sim 0.02 \mathrm{mo}^{-1}$. This value is about 1 order of magnitude lower than growth rates (i.e. net change in number of polyps) found for tropical species, e.g. 0.13 or $0.49 \mathrm{mo}^{-1}$ for Zoanthus sociatus, 
Ellis, $0.42 \mathrm{mo}^{-1}$ for $Z$. solanderi, Lesuer, and from 0.15 to 0.24 for Palythoa caribaerorum (Duchassaing and Michelotti) (Sebens 1982, Karlson 1988).

The small difference between mean growth $\left(0.11 \mathrm{mo}^{-1}\right)$ and shrinkage $\left(0.09 \mathrm{mo}^{-1}\right)$ rates obtained for $P$. axinellae indicates that this species shows a great 'mobility' with succesive growth and recession. This may be interpeted as a continuous search for favorable microhabitats to grow into. It is probable that tropical species would have shown even higher values of net growth if independent measures on growth and shrinkage had been obtained. However, measures based only on counting polyps may provide a conservative measure on the dynamics of species.

The mentioned small difference between mean shrinkage and growth rates in Parazoanthus axinellae suggests that shrinkage may play an important role in the growth dynamics of this species. Though factors involved in the shrinkage were not specifically investigated in this study, some remarks can be made. Presumably, recession (from previously colonized areas) and fission processes could be the main reason for quantified shrinkage rates. Sources of partial as well as whole mortality, such as physical disturbances and substrate dislodgment, could also account for some loss. Predation by polychatea and fishes can be important in some tropical zoanthids (Sebens 1982), but predation on $P$. axinellae was not observed during the 2 yr of monitoring.

Alcyonium acaule changed less in size during the 2 yr of study, and growth appears to be a very slow process in this species. This finding supports other studies on the growth of Alcyonacea species in temperate and tropical seas (Sebens 1984, Updike 1991, Fabricius 1995). Consideration of the measured growth rates in $A$. acaule and the non-existence of fission and fusion in this species, which avoids the decoupling between size and age found in many colonial organisms (Hughes \& Jackson 1980), suggests that $A$. acaule is a very longlived species. Thus, for instance, large colonies (>2000 $\mathrm{mm}^{2}$ and with 7 lobes) at the study site might be several decades old.

Colony size reduction was relatively common in $A$. acaule colonies over the $2 \mathrm{yr}$ study period. This finding may be attributed to different factors that can cause partial mortality of colonies (i.e. loss of part of the body biomass). Although determination of causes of partial as well as whole colony mortality was not directly addressed in this study, the following main factors were identified from photographs: physical disturbance (severe water motion and substrate dislodgment), biological disturbance (sea-urchin bulldozing and grazing) and nudibranch predation. A fourth cause of mortality was observed in 3 colonies: colony tissues suffered 'degeneration', becoming soft and then detached from their basal disk. This process was completed in about 1 mo and, although polyps appeared and survived on the remaining basal disk, colonies finally disappeared within the following 2 mo. In another case, this process affected only one half of the colony, while the other half remained healthy and alive. It is interesting to note that these colonies were in contact with or near sponges known to have powerful allelochemicals (Crambe crambe, Schmidt, and Dysidea avara) (Becerro 1994, X. Turon pers. comm.). This circumstantial evidence suggests that allelochemical-mediated interactions may lead to $A$. acaule tissue degeneration and subsequent death.

As has been reported in other studies of marine clonal organisms (e.g. Hughes \& Jackson 1985), A. acaule mortality appeared dependent on colony size. Small colonies $\left(<100 \mathrm{~mm}^{2}\right.$ ) suffered whole mortality more frequently than did large colonies, simply because the latter, being bigger, could stand the biomass losses or escape from whole mortality better than the former, whatever the cause of biomass loss (Connell 1973, Jackson 1979). Thus, for instance, bulldozing by the sea-urchin Paracentrotus lividus could lead to dislodgment of small colonies and not affect large colonies at all. Sebens (1983) demonstrated, for Alcyonium siderium, that small colonies settling near the larger ones have a higher survivorship due to the effective protection of large colonies against the seaurchins' bulldozing or direct predation.

\section{Fission and fusion events}

Parazoanthus axinellae showed remarkable fission rates, while fusion events rarely occurred in this species. High rates of fission events are also common in the development of other zoanthid species (West 1979, Muirhead \& Ryland 1985, Karlson 1986, 1988). Most fission events in $P$. axinellae appear to be an endogenously induced process, as occurs in some tropical species of zoanthids (Muirhead \& Ryland 1985, Karlson 1988). Fission in this species may be interpreted as a strategy to occupy a favorable substratum at rates higher than would be possible by somatic growth. In this sense, it is worth noting the relationship between colony size and rate of fission (large colonies $>100 \mathrm{~mm}^{2}$ underwent fission more frequently than smaller ones), indicating that $P$. axinellae tends to occupy the space with numerous small colonies instead of fewer large colonies. Fission and fragmentation have also been related to increase in space acquisition because relative growth rates of small colonies are greater than larger ones (Hughes 1989, Stoner 1989, Hughes \& Jackson 1985). However, P. axinellae colonies examined (ranging from 0 to $400 \mathrm{~mm}^{2}$ ) showed similar 
growth and shrinkage rates (Fig. 3). On the other hand, they could also have lower survivorship (Highsmith 1982, Hughes \& Jackson 1985). Unfortunately, data obtained on $P$. axinellae mortality are insufficient for a colony-size-dependent mortality relationship to be found. Despite this, it is thought that in coralligenous communities (where $P$. axinellae dwells) physical and biological disturbances may play a minor role (Garrabou 1997) and thus could favor the survivorship of small colonies unless other factors (e.g. competition) come into play and diminish their survival.

Alcyonium acaule, in contrast, does not reproduce asexually by colony fission or fragmentation, nor does it show fusion events. This finding agrees with data reported for other alcyoniid soft coral species which display low rates of fission, fragmentation or budding events or lack of asexual reproduction (Sebens 1984, Fabricius 1995).

\section{Larval recruitment}

Photographic surveys are not useful in assessing Parazoanthus axinellae recruitment rates, due to uncertainty about the asexual or sexual origin of the smallest colonies (those with 1 or few polyps), since these colonies were only observed in plots with dense aggregations of $P$. axinellae. Nevertheless, our observations suggest that sexual reproduction was a minor source of new colonies. In fact, measured fission rates showed that the number of new colonies provided by asexual reproduction was double the number of colonies that died. However, further studies are needed to investigate the role of sexual reproduction in $P$. axinellae populations.

Due to the lack of asexual reproduction, sexual recruitment appeared to be the only way local populations of Alcyonium acaule were maintained. The recruitment and mortality rates measured in this study led to the conclusion that recruitment cannot maintain the population at the study site. However, since recruitment in octocorals appears to show important inter-annual fluctuations (e.g. Benayahu \& Loya 1987. Farrant 1987), further studies based on larger spatial and temporal scales should be conducted to determine the actual rates of sexual recruitment in the populations studied.

\section{Seasonal variations in feeding activity rhythm}

Data on feeding activity rhythms of Parazoanthus axinellae and Alcyonium acaule showed a decrease in activity during summer (Fig. 5). No diel cycle of expansion and contraction was observed in either species, nor has such a cycle been observed in other mediterranean species (Barange \& Gili 1988, Coma et al. 1994, 1995, unpubl. data, M. Ribes pers. comm. but see Boero et al. 1991). Data for both species came from visual counting or photographs carried out at about the same hour of the day, so differences in expansion states should be attributed to other factors. In the study area, summer is characterized by a decrease in sea storms and associated water motion (Pascual \& Flos 1984. Garrabou 1997) and a decrease in zoo- and phytoplankton concentration (Gaudy 1971, 1972, Coma et al. 1994, Ribes et al. in press). Flow rate and prey concentration have been shown to be the main factors regulating feeding in passive suspension feeders (Leversee 1976, Patterson 1991). Thus, diminution in feeding activity may well be related to these environmental conditions. Data available on feeding activity and resting states in other suspension-feeder species suggest that summer may be an unfavourable season for these species in this study area (Boero et al. 1986, Turon \& Becerro 1992, Coma et al. 1994, Ribes 1998).

Dormancy states found in Alcyonium acaule have also been described in other Alcyonacea species. In $A$. siderium there is a short dormancy period in winter (Sebens 1983), while in Alcyonium digitatum (L.) the dormancy state lasts from September to the end of November, and is related to a decrease in food availability and the storage of ripe gametes (Hartnoll 1975). In $A$. acaule, spawning occurs in late June and early July (Lo Bianco 1909, E. Sala pers. comm.) and precedes the occurrence of a great number of colonies in a dormancy state. However, further studies are necessary to elucidate the role of the dormant state in $A$. acaule.

\section{Seasonal variation in growth and shrinkage in Parazoanthus axinellae}

Parazoanthus axinellae showed growth peaks in autumn intervals, indicating that it may respond to the significant seasonal changes in environmental conditions found in the NW Mediterranean. In the study area, autumn is characterized by an increase in sea storms and associated water motion (Pascual \& Flos 1984, Garrabou 1997) and by an increase in zoo- and phytoplankton concentration (Gaudy 1971, 1972. Coma et al. 1994, Ribes et al. in press). Thus, autumn peaks of growth may be related to the greater water movement and availability of prey. However, the lack of studies on feeding in $P$. axinellae and long-term series of $P$. axinellae's prey concentration (which presumably exhibit strong inter-annual variations in time and amplitude) prevent any definitive conclusion. Alternatively, Herberts (1972b) found 2 growth peaks 
in other Mediterranean zoanthid species (Epizoanthus arenaceus ingeborgae Pax, E. paguricola Roule and E. vagus Herberts) dwelling in detritic communities, one in late winter and the other in summer. That author linked the significant decrease in growth in spring to the initiation of gametogenesis. This hypothesis could also apply to $P$. axinellae since mature ovocytes and spermatocytes appeared between summer and autumn (depending on the study area) just before peaks of growth (Herberts 1972a, Gili et al. 1987). However, the sexual reproductive cycle of $P$. axinellae in the Medes Islands should be studied to verify this hypothesis.

Shrinkage rates were almost constant over time except in the last monitored interval (spring-summer 1995). In this interval most of the colonies suffered some shrinkage, whereas in other intervals, half the colonies monitored showed no shrinkage at all. However, no factor has been identified as being responsible for this general shrinkage.

\section{Conclusions}

Parazoanthus axinellae and Alcyonium acaule showed 2 distinct strategies to colonize and persist in the communities where they dwell. Effectively, Parazoanthus axinellae appeared to be a more dynamic species with remarkable growth, shrinkage and fission rates, which enable it to spread rapidly over the substratum. It seems that its sheet-like growth form facilitates this greater 'mobility', due to the lower allocation of energy and materials required (Jackson 1979). In $P$. axinellae, sexual reproduction seems to play a minor role. Instead, fission of colonies seems an effective way of persisting and colonizing new space within the communities. Finally, our findings suggest that the characteristic aggregation pattern of colonies found in this species may originate from the growth and fission of a single or few original founder colonies (i.e. genet) established in the community. Thus, many colonies within such aggregations could be genetically similar.

Alcyonium acaule showed much slower growth and great longevity, in accordance with its massive treelike growth form, which involves a great allocation of energy and materials to somatic growth and also confers a greater resistance to damage from disturbances and to being overgrown by other species (Jackson 1979). The lack of asexual reproduction in $A$. acaule forces it to use sexual reproduction to persist and to colonize new areas. Finally, in contrast with Parazoanthus axinellae, the characteristic aggregation pattern also found in $A$. acaule colonies results from its mode of sexual reproduction. A acaule is a surface brooder (author's pers. obs.) in which eggs are retained by mucous strings for up to a few days, implying a shortrange dispersal for larvae and settlement near the parental colonies. Thus, colonies of aggregations must be genetically different.

Acknowledgements. I acknowledge $M$. Zabala for his guidance and comments throughout this study. The author is also indebted to J. M. Gili for his advice during the preparation of the manuscript and R. N. Hughes, K. Sebens and 1 anonymous reviewer for their valuable comments, which helped to improve and clarify the manuscript. I also thank K. S. and B Badgley for reviewing the English. Thanks are due to $X$ Turon for the use of his programs to perform the permutation tests and for statistical advice. The author is grateful to $\mathrm{E}$. Sala, R. Coma, and M. Ribes for their help in several aspects of this work and N. Teixidor and X. Torras for their help during the computer image processing. This study was supported by the 'Direcció General de Pesca Maritima' of the 'Conselleria d'Agricultura, Ramaderia i Pesca', a department of the 'Generalitat de Catalunya' (Regional Government of Catalonia), Project no. PCC 68003/9.

\section{LITERATURE CITED}

Ayling AL (1983) Growth and regeneration rates in thinly encrusting demospongiae from temperate waters. Biol Bull 165:343-352

Bak RPM, Engel MS (1979) Distribution, abundance and survival of juvenile hermatypic corals (Scleractinia) and the importance of life history stratgies in the parent coral community. Mar Biol 54:341-352

Barange M, Gili JM (1988) Feeding cycles and prey capture in Eudendrium racemosum (Cavolini, 1785). J Exp Mar Biol Ecol 115:281-293

Becerro MA (1994) The toxicity of Crambe crambe. PhD thesis, Universitat de Barcelona

Benayahu Y, Loya Y (1981) Competition for space among coral reef sessile organisms at Eliat, Red Sea. Bull Mar Sci $31: 514-522$

Benayahu Y, Loya Y (1987) Long-term recruitment of softcorals (Octocorallia: Alcyonacea) on artificial substrata at Eilat (Red Sea). Mar Ecol Prog Ser 38:161-167

Boero F, Balduzzi A, Bavestrello G, Caffa B, Vietti RC (1986) Population dynamics of Eudendrium glomeratum (Cnidaria: Anthomedusae) on the Portofino Promontory (Ligurian Sea). Mar Biol 92:81-85

Boero F, Cicogna, Pessano, Pronzato M (1991) In situ observations on contraction behaviour and diel activity of Halcampoides purpurea var. Mediterranean (Cnidaria, Anthozoa) in a marine cave. PSZN I: Mar Ecol PSNI 12(3):185-192

Coma R, Gili JM, Zabala M. Riera T (1994) Feeding and prey capture cycles in the aposymbiontic gorgonian Paramuricea clavata. Mar Ecol Prog Ser 115:257-270

Coma R, Gili JM, Zabala M (1995) Trophic ecology of a benthic marine hydroid Campanularia everta. Mar Ecol Prog Ser 119:211-220

Coma R, Ribes M, Zabala M, Gili JM (1998) Growth in a modular marine invertebrate. Estuar Coastal Shelf Sci 47 : $459-470$

Connell JH (1973) Population ecology of reef building corals. In: Jones OA, Endean R (eds) Biology and geology of corals reefs (Vol. 2). Academic Press, New York, p 205-245

Crowley PH (1992) Resampling methods for computationintensive data analysis in ecology and evolution. Annu Rev Ecol Syst 23:405-47 
Fabricius KE (1995) Slow population turnover in the soft coral genera Sinularia and Sarcophyton on mid-and outer-shelf reefs of the Great Barrier Reef. Mar Ecol Prog Ser 126: 145-152

Farrant PA (1987) Population dynamics of the temperate Australian soft coral Capnella gaboensis. Mar Biol 96:401-407

Fisher RA (1958) The genetical theory of natural selection, 2nd rev edn. Dover Publications, New York

Garrabou J (1997) Structure and dynamics of north-western Mediterranean rocky benthic communities along a depth gradient: a Geographical Information System (GIS) approach. PhD thesis, Universitat de Barcelona

Garrabou J (1998) Applying a Geographical Information System (GIS) to the study of the growth of benthic clonal organisms. Mar Ecol Prog Ser 173:227-235

Gaudy R (1971) Contribution a l'étude du cycle biologique des copépodes pélagiques du golfe de Marseille 1 L'environnement physique et biotique et la composition de la population de copépodes. Tethys 3(4):921-942

Gaudy R (1972) Contribution a la connaissance du cycle biologique des copépodes pélagiques du golfe de Marseille 2 -Etude du cycle biologique de quelques espèces caractéristiques. Tethys 4(1):175-242

Gili JM, Ros JD (1985a). Estudio cuantitativo de tres poblaciones circalitorales de cnidarios benticos (A quantitative study of three circalittoral populations of benthic cnidarians). Invest Pesq (Barc) 49:323-352

Gili JM, Ros JD (1985b) Study and cartography of benthic communities of Medes Islands (NE Spain). PSZN I: Mar Ecol 6:219-238

Gili JM, Garcia A, Colomer PL (1984) Els cnidaris bentònics de les Illes Medes. In: Ros JD, Olivella I, Gili JM (eds) Els sistemes naturals de les illes Medes. Arxius Sec Ciènc Institut d'Estudis catalans, Barcelona 73:407-427

Gili JM, Pagès F, Barange M (1987) Zoantharios (Cnidaria, Anthozoa) de la costa y de la plataforma continental catalanas (Mediterráneo Occidental). Misc Zool 11:13-24

Harmelin JG (1984) Biologie du corail rouge. Paramètres de populations, croissance et mortalité naturelle. Etat des connaissances en France. In: Charbonnier D, Garcia S (eds) Report of GFCM technical consultation on red coral resources of the Western Mediterranean and their rational exploitation. FAO Fisheries Rep 306:99-103

Harper JL (1977) Population biology of plants. Academic Press, London

Hartnoll RG (1975) The annual cycle of Alcyonium digitatum. Estuar Coast Mar Sci 3:71-78

Herberts C (1972a) Étude sysématique de quelques zoantharies tempérés et tropicaux. Tethys 3:69-156

Herberts C (1972b) Contribution a l'étude biologique de quelques zoantharies tempérés et tropicaux II. Relations entre la reproduction sexuée, la croissance somatique et le bourgeonnement. Tethys 4(4):961-968

Highsmith RC (1982) Reproduction by fragmentation in corals. Mar Ecol Prog Ser 7:207-226

Hughes RN (1989) A functional biology of clonal animals. Chapman \& Hall, London

Hughes RN, Cancino JN (1985) An ecological overview of cloning in metazoa. In: Jackson JBC. Buss LW, Cook RE (eds) Population biology and evolution of clonal organisms. Yale University Press, New Haven, p 153-186

Hughes TP, Jackson JBC (1980) Do corals lie about their age? Some demographic consequences of partial mortality, fission, and fusion. Science 209(8):713-714

Hughes TP, Jackson JBC (1985) Population dynamics and life histories of foliaceous corals. Ecol Monogr 55(2):141-166

Jackson JBC (1977) Competition on marine hard substrata: the adaptive significance of solitary and colonial strategies. Am Nat 3:743-767

Jackson JBC (1979) Morphological strategies of sessile animals. In: Larwood G, Rosen BR (eds) Biology and systematics of colonial organisms. Academic Press, London, p 499-555

Karlson RH (1986) Disturbance, colonial fragmentation, and size dependent life history variation in 2 coral reef cnidarians. Mar Ecol Prog Ser 28:245-249

Karlson RH (1988) Size-dependent growth in two zoanthid species: a contrast in clonal strategies. Ecology 69(4): $1219-1232$

Leversee GJ (1976) Flow and feeding in fan-shaped colonies of the gorgonian coral, Leptogorgia. Biol Bull 151:344-456

Llobet I, Coma R, Zabala M, Gili JM. Hughes RG (1991) The population dynamics of Orthopyxis crenata (Hartlaub, 1901) (Hydrozoa, Cndidaria), epiphyte of Halimeda tuna in the Northwestern Mediterranean. J Exp Mar Biol Ecol 150:283-292

Lo Bianco S (1909) Notizie biologiche riguardanti specialmente il periodo de maturita sessuale degli animali del golfo di Napoli. Mitt Zool Ston Neapel 19:513-761

Manly BFJ (1991) Randomization and Monte Carlo methods in biology. Chapman \& Hall, London

Mistri M, Ceccherelli VU (1994) Growth and secondary production of the Mediterranean gorgonian Paramuricea clavata. Mar Ecol Prog Ser 103:291-296

Muirhead A, Ryland JS (1985) A review of the genus Isaurus Gray 1828 (Zoanthidea), including new records from Fiji. J Nat Hist 19:323-335

Pascual J, Flos J (1984) Meteorologia i oceanografia. In: Ros JD, Olivella I, Gili JM (eds) Els sistemes naturals de les illes Medes. Arxius Sec Ciènc Institut d'Estudis Catalans, Barcelona 73:75-114

Patterson MR (1991) Passive suspension feeding by an octocoral in plankton patches: empirical test of a mathematical model. Biol Bull 180:81-92

Pérès JM, Picard J (1964) Nouveau manuel de bionomie benthique de la mer Méditerranée. Recl Trav Stn Mar Endoume 31(47):1-131

Pianka ER (1976) Natural selection of optimal reproductive tactics. Am Zool 16:775-784

Ribes M (1998) Feeding activity and diet of benthic suspension feeders related to metabolic requirements and seston composition. PhD thesis, Universitat de Barcelona

Ribes M, Coma R, Gili JM (in press) Seasonal variations of POC, DOC and the contribution of microbial communities to the live POC in a shallow near-bottom ecosystem at the northwestern Mediterranean Sea. J Plankton Res

Sebens KP (1982) Intertidal distribution of zoanthids on the caribbean coast of Panama: effects of predation and desiccation. Bull Mar Sci 32(1):316-335

Sebens KP (1983) The larval and juvenile ecology of the temperate octocoral Alcyonium siderium Verrill. II Fecundity. survival, and juvenile growth. J Exp Mar Biol Ecol 72 $263-285$

Sebens KP (1984) Water flow and coral colony size: interhabitat comparisons of the octocoral Alcyonium siderium. Proc Natl Acad Sci USA 8:5473-5477

Stearns SC (1992) The evolution of life histories. Oxford University Press, New York

Stoner DS (1989) Fragmentation: a mechanism for the stimulation of genet growth rates in an encrusting colonial ascidian. Bull Mar Sci 45(2):277-287

True MA (1970) Étude quantitative de quatre peuplements sciaphiles sur substrat rocheux dans la région marseillaise. Bull Inst Océanogr Monaco 1410:1-48 
Turon X. Becerro MÁ (1992) Growth and survival of several ascidian species from the northwestern Mediterranean. Mar Ecol Prog Ser 82:235-247

Turon X. Tarjuelo I, Uriz MJ (1998) Growth dynamics and mortality of the encrusting sponge Crambe crambe (Poecilosclerida) in contrasting habitats: correlation with population structure and investment in defence. Funct Ecol $12(4) \cdot 631-639$

Updike D (1991) Reproductive biology and ecology of the temperate zone octocoral Gersemia rubiformis. MSc thesis, Northeastern University, Boston

Waldford L.A. (1946) A new graphic method of describing the growth of animals. Biol Bull 141-147

Editorial responsibility: Roger Hughes (Contributing Editor) Bangor, Gwynedd, UK
Weinberg S (1975) Ecologié des octocoralliaires communs sur substrat dur dans la region de Banyuls-sur-Mer. Essay d'une mèthode. Bijdr Dierkd 45:50-70

Weinberg S (1977) Revision of common Octocorallia of the Mediterranean circalittoral II. Alcyonacea. Beaufortia 25(326): $131-166$

Weinberg S (1978) Mediterranean octocorallian communities and the abiotic environment. Mar Biol 49:41-57

Weinberg S, Weinberg F (1979) The life cycle of a gorgonian Eunicella singularis (Esper, 1794). Bijdr Dierkd 1(49) $16-30$

West DA (1979) Symbotic zoanthids (Anthozoa, Cnidaria) of Puerto Rico. Bull Mar Sci 29(2):253-271

Submitted: July 10, 1998; Accepted: November 13, 1998 Proofs received from author(s): March 9, 1999 